\title{
Anti-Tumor Effects of Liposome-Encapsulated Titanium Dioxide in Nude Mice
}

\author{
Yoshitomo Chihara $^{a}$ Kiyohide Fujimoto $^{a}$ Hideaki Kondo $^{a}$ Yukiko Moriwaka $^{b}$ \\ Tomonori Sasahira $^{\text {b }}$ Yoshihiko Hirao $^{\text {a }}$ Hiroki Kuniyasu $^{b}$ \\ Departments of a Urology and ${ }^{\mathrm{b}}$ Molecular Pathology, Nara Medical University School of Medicine, Kashihara, Japan
}

\section{Key Words}

Apoptosis • Bladder cancer • Liposome • Oxidative stress • $\mathrm{TiO}_{2}$

\begin{abstract}
Anatase particles of titanium dioxide $\left(\mathrm{TiO}_{2}\right)$ absorb ultraviolet (UV) light which is shorter than $415 \mathrm{~nm}$. Photoexcited $\mathrm{TiO}_{2}$, a strong oxidizer, is expected to inhibit malignant cell growth. Liposomes accelerate endophagocytosis to the cytoplasm of encapsulated materials. In this study, we examined anti-tumor effects of $\mathrm{TiO}_{2}$ and liposome-encapsulated $\mathrm{TiO}_{2}$ (LT) with UVA irradiation by an air pouch cancer model using NBT-II bladder cancer cells, which simulates bladder cancer. Injection of $\mathrm{TiO}_{2}$ or LT into the air pouch was followed by UVA irradiation via the opened pouch. Tumors of $\mathrm{TiO}_{2}+$ UVA and LT + UVA groups showed more pronounced necrotic areas, apoptotic indices, nitrotyrosine formation, tumor growth inhibition and increased survival compared with control groups. Especially the LT + UVA group showed more remarkable anti-tumoral effects than the $\mathrm{TiO}_{2}+$ UVA group, which was associated with higher $\mathrm{TiO}_{2}$ incorporation. These findings suggest that LT might be more effective than noncoated $\mathrm{TiO}_{2}$ in the treatment of bladder cancer.
\end{abstract}

Copyright $\odot 2007$ S. Karger AG, Basel

Abbreviations: $\mathrm{LT}=$ liposome-encapsulated $\mathrm{TiO}_{2} ; \mathrm{PBS}=$ phosphatebuffered saline; PDT = photodynamic therapy; UV = ultraviolet.

\section{KARGER}

Fax +41613061234 E-Mail karger@karger.ch www.karger.com
(C) 2007 S. Karger AG, Basel

$1015-2008 / 07 / 0746-0353 \$ 23.50 / 0$

Accessible online at:

www.karger.com/pat

\section{Introduction}

Titanium dioxide $\left(\mathrm{TiO}_{2}\right)$ is a semiconductor. When anatase-type $\mathrm{TiO}_{2}$ particles absorb ultraviolet (UV) light shorter than $415 \mathrm{~nm}(3.0 \mathrm{eV})$ corresponding to the band gap of $\mathrm{TiO}_{2}$, it creates an electron hole pair [1]. Two mechanisms of the $\mathrm{TiO}_{2}$ photocatalyst reaction have been proposed [2]. One is the direct action of photoexcited $\mathrm{TiO}_{2}$ on cells. Photoexcited $\mathrm{TiO}_{2}$ is a strong oxidizer, and it is expected that the cells are directly oxidized by the holes formed in the balance band. The other proposed process is the indirect action. Hydroxyl radicals $(\mathrm{OH} \cdot)$ and/or perhydroxy radicals $\left(\mathrm{HO}_{2}{ }^{\circ}\right)$ generated from $\mathrm{H}_{2} \mathrm{O}$ may attack proteins and lipids in the cell membrane and cellular components. Kubota et al. [3, 4] and Gai et al. [3, 4] reported that strong oxidation by $\mathrm{TiO}_{2}$ inhibits malignant cell growth. In an in vivo study, $\mathrm{TiO}_{2}$ particles alone showed no toxicity to experimental animals [3].

In Japan, approximately 5,000 patients die from bladder cancer every year [5]. The intravesical cavity can be easily observed through an endoscope. Cancer in the vesicular cavity can be treated with superficial application of $\mathrm{TiO}_{2}$ combined with UV irradiation. In this study, we used an air pouch model formed in mouse subcutaneous tissue to obtain an animal model simulating bladder cancer, i.e. cancer in a cavity. We investigated the antitumoral effect of the photocatalytic activity of $\mathrm{TiO}_{2}+$ UVA in comparison with liposome-encapsulated $\mathrm{TiO}_{2}$ (LT). Thus, bladder cancer is an adequate model for photodynamic therapy (PDT).

Dr. Hiroki Kuniyasu

Department of Molecular Pathology, Nara Medical University School of Medicine 840 Shijo-cho

Kashihara, Nara 734-8521 (Japan)

Tel. +81 72222 3015, Fax +81 72225 7308, E-Mail cooninh@zb4.so-net.ne.jp 
Table 1. Necrotic and apoptotic effects of LT

\begin{tabular}{llcl}
\hline Group & $\begin{array}{l}\text { Necrotic } \\
\text { area, } \%\end{array}$ & $\begin{array}{l}\text { Apoptotic } \\
\text { index, } \%\end{array}$ & $\begin{array}{l}\text { Nitrotyrosine } \\
\text { concentration, nM }\end{array}$ \\
\hline $\mathrm{PBS}$ & $13 \pm 2^{\mathrm{a}, \mathrm{b}}$ & $2 \pm 1^{\mathrm{a}, \mathrm{b}}$ & $43 \pm 12^{\mathrm{c}, \mathrm{d}}$ \\
$\mathrm{LT}$ & $14 \pm 2$ & $3 \pm 1$ & $47 \pm 14$ \\
$\mathrm{TiO}_{2}+\mathrm{UVA}$ & $45 \pm 6^{\mathrm{a}, \mathrm{c}}$ & $14 \pm 3^{\mathrm{a}, \mathrm{e}}$ & $471 \pm 97^{\mathrm{a}, \mathrm{c}}$ \\
$\mathrm{LT}+\mathrm{UVA}$ & $77 \pm 10^{\mathrm{b}, \mathrm{c}}$ & $22 \pm 4^{\mathrm{b}, \mathrm{e}}$ & $971 \pm 289^{\mathrm{a}, \mathrm{d}}$ \\
\hline
\end{tabular}

${ }^{\mathrm{a}} \mathrm{p}<0.0005 ;{ }^{b} \mathrm{p}<0.0001 ;{ }^{\mathrm{c}} \mathrm{p}<0.001,{ }^{\mathrm{d}} \mathrm{p}<0.005 ;{ }^{\mathrm{e}} \mathrm{p}<0.01, \mathrm{cal}-$ culated by Mann-Whitney test.

\section{Materials and Methods}

\section{Cell Culture}

A rat urinary bladder cancer cell line, NBT-II (Dainihon, Tokyo, Japan), was grown in E-MEM (Sigma, St. Louis, Mo., USA) supplemented with $10 \%$ fetal bovine serum at $37^{\circ} \mathrm{C}$ in a humidified atmosphere with $5 \% \mathrm{CO}_{2}$ in air.

\section{Preparation of $\mathrm{TiO}_{2}$ and $\mathrm{LT}$}

$\mathrm{TiO}_{2}$ particles (anatase, AMT-100, Teika, Tokyo, Japan; mean diameter: $6 \mathrm{~nm}$ ) were suspended in PBS, ultrasonically dispersed and sterilized using an autoclave. $\mathrm{TiO}_{2}$ particles 100 and $50 \mathrm{~nm}$ in diameter were hardly incorporated into liposomes. The $\mathrm{TiO}_{2}$ aqueous suspension $(2 \mathrm{ml}$ ) was added to empty liposome preparations (EL-C-01, DPPC: 26 mM, Nippon-Oil \& Fats, Tokyo, Japan). The amount of $\mathrm{TiO}_{2}$ particles in the suspension was measured with an inductively coupled plasma atomic emission spectrometer (ICPS-1000 III, Shimadzu, Kyoto, Japan). Treatment solutions were prepared to contain $400 \mu \mathrm{g} / \mathrm{ml}$ of $\mathrm{TiO}_{2}$. The dosage of $\mathrm{TiO}_{2}$ is set to be $400 \mu \mathrm{g}$ for each tumor.

\section{UV Irradiation}

UVA irradiation (peak length $365 \mathrm{~nm} ; 5 \mathrm{~J} / \mathrm{cm}^{2}$ ) was performed with an UV lamp (xx-15 BLB; UVP, Tokyo, Japan). UVB and UVC with wavelengths $<330 \mathrm{~nm}$ were cut with an UV cut filter (UV-33, Toshiba, Tokyo, Japan).

\section{Anti-Tumor Effects in an Air Pouch Model in Nude Mice}

Thirty male BALB/c nu/nu mice (SLC Japan, Shizuoka, Japan), 4 weeks old, were inoculated with a single-cell suspension of $5 \times$ $10^{6}$ NBT-II cells with $0.2 \mathrm{ml}$ PBS into the subscapular subcutaneous tissue. When tumors reached $5 \mathrm{~mm}$ in diameter, air $(3 \mathrm{ml})$ was injected into the subcutaneous tissue surrounding the tumor to form an air space. These mice were then subjected to different treatments: PBS alone (PBS group), LT without UVA irradiation (LT group), $\mathrm{TiO}_{2}$ with UVA ( $\mathrm{TiO}_{2}+$ UVA group) and LT with UVA (LT + UVA group). To examine the direct effects of these substances, $\mathrm{TiO}_{2}$ or LT solutions were injected into the subcutaneous air pouch. After $3 \mathrm{~h}$ of incubation, the pouch was opened in order to expose the tumor surface. The tumor surface was irradiated with UVA, and the skin incision was closed. Two mice from each group were sacrificed $24 \mathrm{~h}$ after treatment for histological examination. Six other mice per group were monitored for tumor growth and survival.

\section{Histological Examination}

Thin sections $(4 \mu \mathrm{m})$ of the archival specimens were immunostained with anti-single-strand DNA antibody (IBL, Takasaki, Japan) to detect single-strand DNA breaks in cells caused by free radicals produced through UVA-excited $\mathrm{TiO}_{2}$ [6]. Tissue image of hematoxylin-eosin staining was captured into computer and necrotic area was marked and calculated by NIH image (National Institutes of Health, Bethesda, Md., USA). Cells positive for antisingle-strand DNA antibody per 500 cells were counted using a microscope.

\section{Enzyme-Linked Immunosorbent Assay (ELISA) for}

Nitrotyrosine

ELISA for anti-nitrotyrosine antibody (Hycult Biotechnology, Uden, The Netherlands) was performed according to the manufacturer's instructions for 3 times to detect oxidative stress $[7,8]$. Whole lysates were extracted from liquid nitrogen-frozen tumor materials according to the method described previously [9].

Detection of Tissue-Incorporated $\mathrm{TiO}_{2}$

Thin sections of the tumor archival specimen were dewaxed and hydrated with PBS and solubilized by boiling with $5 \mathrm{M}$ acid guanidine sulfate for $10 \mathrm{~min}$. $\mathrm{TiO}_{2}$ suspended in $5 \mathrm{M}$ acid guanidine sulfate-containing bovine serum albumin $(1 \mu \mathrm{g} / \mu \mathrm{l}$, Sigma, St. Louis, Mo., USA) was used as a control. Tissue extracts (20 $\mu \mathrm{g} / 20 \mu \mathrm{l})$ and $\mathrm{TiO}_{2}$ suspension $(20 \mu \mathrm{l})$ were put into a 48 -well dish and irradiated with UVA $\left(10 \mathrm{~J} / \mathrm{cm}^{2}\right)$ followed by addition of methanol $(80 \mu \mathrm{l}$ ). Then $100 \mu \mathrm{g}$ of DPPP (diphenyl-1-pyrenyl phosphine) in $100 \mu \mathrm{l}$ chloroform (Dojindo, Kumamoto, Japan) were mixed with samples, and fluorescence intensity $(\lambda 380 \mathrm{~nm})$ was measured.

\section{Statistical Analyses}

Statistical significance was examined by the unpaired MannWhitney test (nonparametric difference), the Kaplan-Meier model (survival curve), the Cox proportional hazard model (survivals) and Spearman's rank test (nonparametric correlation; Statview 4.5, Abacus Concepts, Berkeley, Calif., USA). Statistical significance was defined as a two-sided $\mathrm{p}$ value $<0.05$.

\section{Results}

\section{Necrotic and Apoptotic Effects of $\mathrm{TiO}_{2}$ and LT with UVA Irradiation}

To confirm anti-tumor effects of $\mathrm{TiO}_{2}$ and LT, the subcutaneous tumors were analyzed histologically in each group $24 \mathrm{~h}$ after treatment. Firstly, necrotic areas

Fig. 1. Necrotic and apoptotic effect of $\mathrm{TiO}_{2}$ or LT. a-f Histology of tumors treated with PBS (a, d), $\mathrm{TiO}_{2}+\operatorname{UVA}(\mathbf{b}, \mathbf{e}), \mathrm{LT}+\mathrm{UVA}$ (c, f). a, c, e H \& E staining. b, d, f Necrotic areas (8, 33, and 84\%, respectively) are shown in black. Bar $=200 \mu \mathrm{m}$. g-j Single-strand DNA-positive apoptotic cells were detected in 6, 4, 16 and 32\% cells in tumors of PBS (g), LT (h), $\mathrm{TiO}_{2}+\mathrm{UVA}(\mathbf{i})$ and LT + UVA (j) groups, respectively. $\mathrm{Bar}=100 \mu \mathrm{m}$. 

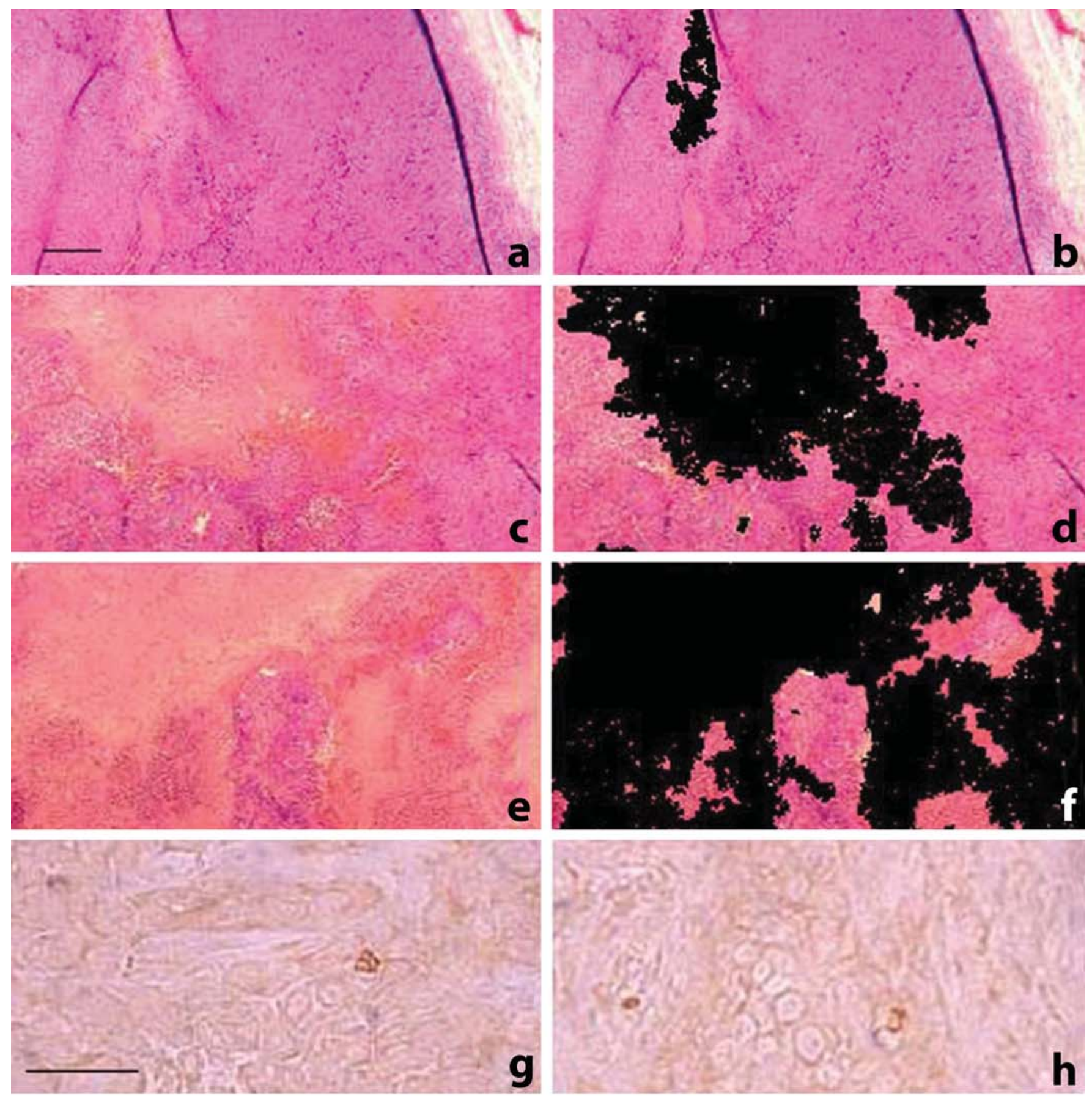

g
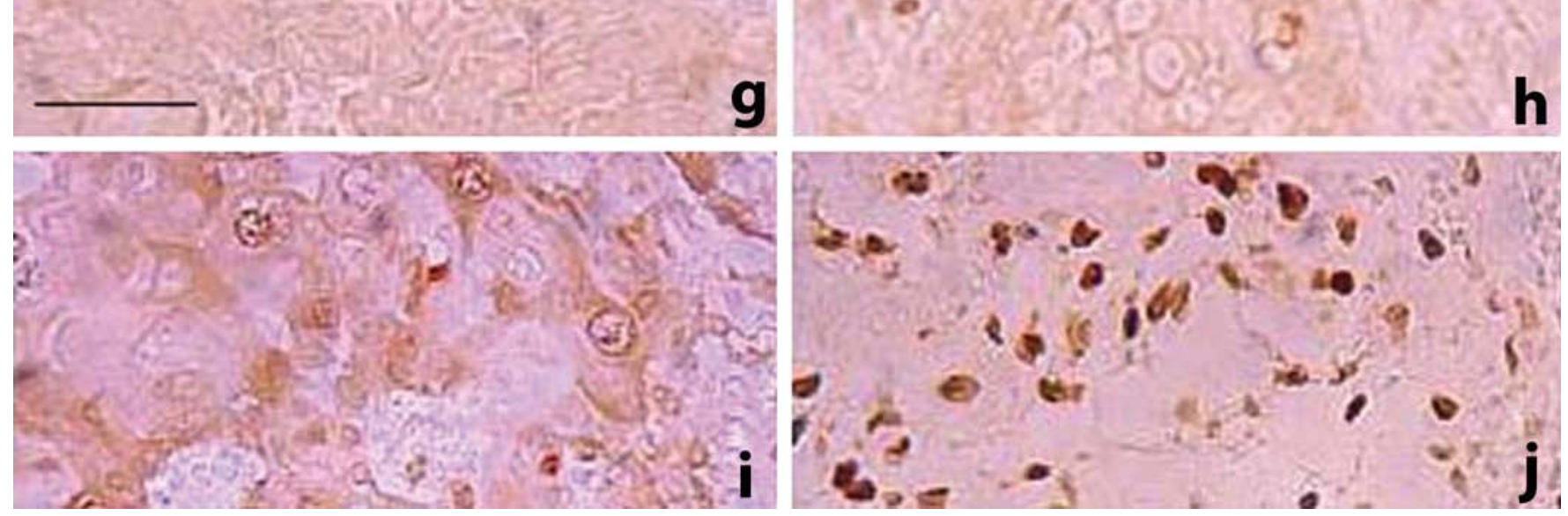
Fig. 2. Incorporation of $\mathrm{TiO}_{2}$ aggregates in tumor tissue. Tissue incorporation of $\mathrm{TiO}_{2}$ was examined by UVA-evoked $\mathrm{TiO}_{2}$-derived hydroperoxide detected by DPPP fluorescence intensity. a Standard curve between $\mathrm{TiO}_{2}$ and generated hydroperoxide. $\mathbf{b} \mathrm{TiO}_{2}$ content in tumor tissue treated with PBS, $\mathrm{TiO}_{2}+$ UVA (T + UVA) and LT + UVA ( $p<0.005$, vs. LT + UVA). Bars show standard deviations.
Fig. 3. Tumor growth and survival in the PBS, $\mathrm{TiO}_{2}+$ UVA $(\mathrm{T}+\mathrm{UVA})$ and $\mathrm{LT}+$ UVA groups. a Mean diameter ( $\mathrm{mm}$ ) of the tumors. Bars indicate standard deviations. b Kaplan-Meier analysis of survival. ${ }^{*} \mathrm{p}<$ 0.005 .
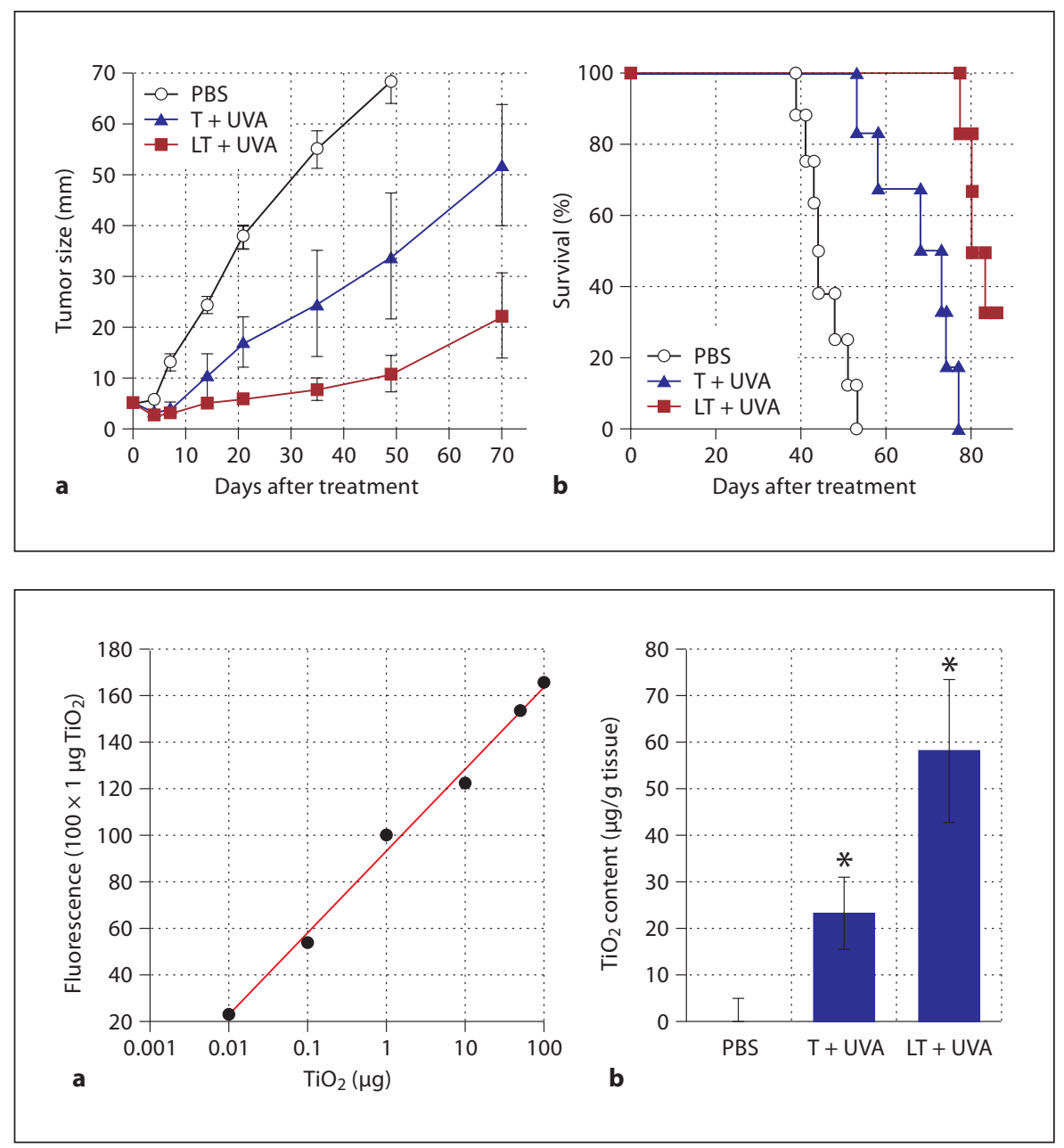

and apoptotic indices were examined in the tumors (fig. la-f, table 1). Tumors treated with $\mathrm{TiO}_{2}+\mathrm{UVA}$ or LT + UVA showed large necrotic areas at the surface and internal regions of the tumors (fig. $1 \mathrm{a}-\mathrm{f}$ ). $\mathrm{TiO}_{2}+\mathrm{UVA}$ and LT + UVA groups demonstrated a more pronounced necrotic effect than PBS or LT groups $(\mathrm{p}<0.0005$, and $\mathrm{p}<0.0001$, respectively). LT + UVA treatment yielded higher necrotic effects than $\mathrm{TiO}_{2}+$ UVA treatment $(\mathrm{p}<$ 0.0001). In the periphery of the necrotic areas, singlestrand DNA-positive apoptotic cells were detected (fig. 1g-j, table 1). PBS and LT groups showed low apoptotic indices. $\mathrm{TiO}_{2}+\mathrm{UVA}$ and LT + UVA groups showed apoptosis in $14 \pm 3$ and $22 \pm 4 \%$ cells in the tumors, respectively, which were higher than those in PBS and LT groups ( $\mathrm{p}<0.0005$ and $\mathrm{p}<0.0001$, respectively). LT + UVA showed higher apoptotic effects than $\mathrm{TiO}_{2}+$ UVA $(\mathrm{p}<0.001)$.
Oxidative Stress by $\mathrm{TiO}_{2}$ and LT with UVA

Irradiation

Oxidative stress generated by $\mathrm{TiO}_{2}+$ UVA or LT + UVA in tumors was examined by nitrotyrosine formation, i.e. major oxidative products $[7,8]$ (table 1). Nitrotyrosine concentrations in $\mathrm{TiO}_{2}+\mathrm{UVA}$ or LT + UVA groups were $471 \pm 97$ and $971 \pm 289 \mathrm{nM}$, respectively, which were higher than those in PBS and LT groups ( $<<0.001$, and $\mathrm{p}<0.005$, respectively). LT + UVA generated more nitrotyrosine than $\mathrm{TiO}_{2}+$ UVA $(\mathrm{p}<0.0005)$. Nitrotyrosine concentration was correlated with the necrotic area and apoptotic index $(\mathrm{p}=0.0001$ and $\mathrm{p}=0.0002$, respectively).

\section{Incorporation of $\mathrm{TiO}_{2}$ in Tumors}

To confirm incorporation of $\mathrm{TiO}_{2}$ in the tumor tissue, in vitro hydroperoxide generation by UVA-excited $\mathrm{TiO}_{2}$ was examined (fig. 2). A standard curve showed good 
Table 2. Correlation between $\mathrm{TiO}_{2}$ incorporation and necrosis, apoptosis, nitrotyrosine concentration and the $50 \%$ survival period

\begin{tabular}{llll}
\hline & S-test & $95 \% \mathrm{CI}$ & p value \\
\hline Necrotic area & 0.6144 & $0.3175-0.8790$ & 0.0015 \\
Apoptotic index & 0.5877 & $0.1518-0.8322$ & 0.0103 \\
Nitrotyrosine concentration & 0.6144 & $0.1923-0.8446$ & 0.0067 \\
50\% survival period & 0.6295 & $0.2160-0.8516$ & 0.0051 \\
\hline
\end{tabular}

Nonparametric correlation was calculated by Spearman rank test (S-test). CI = Confidence interval.

correlation between $\mathrm{TiO}_{2}$ content and hydroperoxide production (fig. 2a). In tumor tissue, equivalent $\mathrm{TiO}_{2}$ content to hydroperoxide generation was significantly higher in the LT + UVA group than that in the $\mathrm{TiO}_{2}+$ UVA group (fig. $2 \mathrm{~b}, \mathrm{p}<0.005$ ). $\mathrm{TiO}_{2}$ incorporation was correlated with necrotic area, apoptotic index and nitrotyrosine concentration (table $2, \mathrm{p}=0.0015, \mathrm{p}=0.0103$, and $\mathrm{p}=0.0067$, respectively).

\section{Tumor Growth and Survival in Mice Treated with}

\section{$\mathrm{TiO}_{2}$ and $\mathrm{LT}$ with UVA Irradiation}

Tumor growth and survival were examined (fig. 3). The tumors in $\mathrm{TiO}_{2}+$ UVA and LT + UVA groups showed slower growth in comparison with tumors in the PBS group $\left(\mathrm{TiO}_{2}+\right.$ UVA vs. PBS; $\mathrm{p}<0.005$, LT + UVA vs. PBS; $\mathrm{p}<0.001)$. Survival in $\mathrm{TiO}_{2}+\mathrm{UVA}$ and $\mathrm{LT}+\mathrm{UVA}$ mice was longer than in PBS mice $\left(\mathrm{TiO}_{2}+\mathrm{UVA}\right.$ vs. PBS; $\mathrm{p}<$ 0.005 , LT + UVA vs. PBS; $\mathrm{p}<0.001)$. Fifty percent survival periods were 44, 73 and 83 days in $\mathrm{PBS}, \mathrm{TiO}_{2}+\mathrm{UVA}$, and LT + UVA, respectively. LT + UVA treatment yielded slower tumor growth and longer survival than $\mathrm{TiO}_{2}+$ UVA treatment $(\mathrm{p}<0.01)$. Fifty percent survival periods of all mice were significantly correlated with $\mathrm{TiO}_{2}$ incorporation (table $2, \mathrm{p}=0.0051$ ).

\section{Discussion}

PDT is one of the local treatments with selective antitumor effects. Photosensitizers, oncotropic optical photoreactive chemical compounds and low-output lasers are used for PDT. Recently, similar to urological cancers, good results of PDT have been reported for the intravesical 5-aminolevulinic acid treatment [10]. We examined the efficacy of $\mathrm{TiO}_{2}$ and LT as photosensitizers in the present study.

Anti-Tumor Effects of

Liposome-Encapsulated $\mathrm{TiO}_{2}$
To confirm the anti-tumoral effect of the $\mathrm{TiO}_{2}$ photocatalyst reaction, we compared $\mathrm{TiO}_{2}$ tissue incorporation with tumor necrosis, apoptosis and nitrotyrosine formation. The $\mathrm{TiO}_{2}$ photocatalyst reaction induces oxidation of cellular components, which results in both necrosis and apoptosis [11]. $\mathrm{TiO}_{2}$ incorporation was correlated with the necrotic area, apoptotic index, nitrotyrosine concentration and $50 \%$ survival periods. Nitrotyrosine is an oxidative product of tyrosine reacting with nitric peroxide [7]. PBS and LT without UVA resulted in minimal nitrotyrosine levels. In contrast, nitrotyrosine was generated in tumors of $\mathrm{TiO}_{2}+\mathrm{UVA}$ or $\mathrm{LT}+\mathrm{UVA}$ groups, which was closely associated with $\mathrm{TiO}_{2}$ incorporation. These results suggest that UVA-evoked $\mathrm{TiO}_{2}$-dependent oxidative stress is responsible for the anti-cancer effect of $\mathrm{TiO}_{2}$.

$\mathrm{TiO}_{2}$ incorporation into cells depends on phagocytosis, and the incorporated $\mathrm{TiO}_{2}$ is metabolized by macrophages [3]. LT facilitated incorporation into tumor tissue, which was expected to enhance intracellular $\mathrm{TiO}_{2}$ concentration. Comparing LT and $\mathrm{TiO}_{2}$, LT + UVA groups showed 2.5 times higher $\mathrm{TiO}_{2}$ incorporation in tumor tissue than $\mathrm{TiO}_{2}+$ UVA groups. Because liposomes are rapidly internalized into cells, LT particles are more effectively transferred to the target cells than noncoated $\mathrm{TiO}_{2}$.

Liposomes have been employed as drug carriers in in vitro and in vivo studies [12, 13]. Four mechanisms are proposed for the interaction of liposomes with cells [14]: (1) stable adsorption - the association between intact liposomes and cell surfaces without entering the cell, (2) endocytosis - intact liposomes delivered to endocytotic vesicles, (3) lipid transfer - lipid exchange between cells and liposomes without the cell interacting with the aqueous content of the liposome and (4) fusion - the liposome bilayer fuses with the cell plasma membrane depositing the contents of the liposome into the cytoplasmic space. In this study, liposomes might suggest two more advantages: firstly, polar photosensitizer can pass the cellular membrane barrier when encapsulated within liposomes, and secondly, water-insoluble photosensitizer can be administered to the cell. In the in vitro treatment, cationic liposomes showed growth inhibition in NBT-II cells (data not shown). However, cytotoxicity was negligible in animals. Excess liposomes may be washed out from the stromal tissue by the blood circulation.

In conclusion, our data suggest adjuvant therapy in bladder cancer as a possible treatment option. A combination of transurethral resection and endoscopic $\mathrm{TiO}_{2}$ liposome PDT might be beneficial in the treatment of superficial and invasive bladder cancer.

Pathobiology 2007;74:353-358 


\section{References}

1 Fujishima A, Honda K: Electrochemical photolysis of water at a semiconductor electode. Nature 1972;238:37-38.

-2 Gai R, Hashimoto K, Itoh K, Kubota Y, Fujishima A: Photokilling of malignant cells with ultrafine $\mathrm{TiO}_{2}$ powder. Bull Chem Soc Jpn 1991;64:1268-1273.

$\checkmark 3$ Kubota Y, Shuin T, Kawasaki C, Hosaka M, Kitamura H, Cai R, Sakai H, Hashimoto K, Fujishima A: Photokilling of T-24 human bladder cancer cells with titanium dioxide. Br J Cancer 1994;70:1107-1111.

4 Gai R, Kubota Y, Shuin T, Sakai H, Hashimoto K, Fujishima A: Induction of cytotoxicity by photoexcited $\mathrm{TiO}_{2}$ particles. Cancer Res 1992;52:2346-2348.

5 Kakiuchi T (ed): Cancer Statistics 2005. National Cancer Center Cancer Information Service. www.ncc.go.jp/jp/statistics/2005/, 2005.
6 Kawarada Y, Miura N, Sugiyama T: Antibody against single-stranded DNA useful for detecting apoptotic cells recognizes hexadeoxynucleotides with various base sequences. J Biochem 1998;123:492-498.

7 Beal MF: Oxidatively modified proteins in aging and disease. Free Radic Biol Med 2002; 32:797-803

8 Beckman JS, Carson M, Smith CD, Koppenol WH: ALS, SOD and peroxynitrite. Nature 1993;364:584.

$\checkmark 9$ Kuniyasu H, Yasui W, Kitahara K, Naka K, Yokozaki H, Akama Y, Hamamoto T, Tahara $\mathrm{H}$, Tahara E: Growth inhibitory effect of interferon-beta is associated with the induction of cyclin-dependent kinase inhibitor p27Kip1 in a human gastric carcinoma cell line. Cell Growth Differ 1997;8:47-52.

10 Jichlinski P, Leisinger $\mathrm{H}$ : Photodynamic therapy in superficial bladder cancer: past, present and future. Urol Res 2001;29:396405.
11 Higuchi Y: Chromosomal DNA fragmentation in apoptosis and necrosis induced by oxidative stress. Biochem Pharmacol 2003; 66:1527-1535.

12 Sargent JM, Elgie AW, Williamson CJ, Lewandowicz GM, Taylor CG: In vitro sensitivity to the liposomal preparation, DaunoXome in CLL. Anticancer Res 1999;19: 3253-3258.

13 Frangos DN, Killion JJ, Fan D, Fishbeck RC, von Eschenbach AC, Fidler IJ: The development of liposomes containing interferon alpha for the intravesical therapy of human superficial bladder cancer. J Urol 1990;143: 1252-1256.

14 Egerdie RB, Reid G, Trachtenberg J: The effect of liposome encapsulated antineoplastic agents on transitional cell carcinoma in tissue culture. J Urol 1989;142:390-398. 